\title{
次世代「つながる」超精密光計測への挑戦
}

\section{A Challenge for the Next-Generation "Connected" Ultra-Precision Optical Metrology}

\author{
○正 清水 裕樹（東北大） 正 松隈 啓（東北大） \\ 正高偉（東北大）
}

Yuki SHIMIZU, Tohoku University, 6-6-01, Aramaki Aza-Aoba, Aoba-ku, Sendai, Miyagi

Hiraku MATSUKUMA, Tohoku University

Wei GAO, Tohoku University

Key Words: Optical metrology, Precision positioning, Angle measurement, Scale grating

\section{1. はじめに}

レーザ干渉計に代表される光計測技術の発展に伴い, 個々の計測機器において 1 自由度の変位計測についてはナ ノメートル超級の高分解能計測が実現されている。その一 方で，ナノ精度機械加工の現場では，3 次元空間内における 多自由度変位・姿勢の超高精度計測に対する要求が高まっ ており，特に近年では国家標準にトレーサブルな計測の実 現が求められている，筆者らは，次世代の「つながる工場」 において必須となる，国家標準にトレーサブルな超高精度・ 高確度・高安定計測技術の確立を目指し, 時間・周波数の国 家標準とダイレクトにリンクし，長さの国家標準でもある モード同期フェムト秒レーザ (光周波数コム) と光ナノグリ ッドを融合で実現する，次世代の「つながる」超精密光計測 (図 1) の新原理を提案している.

\section{2. モード同期フェムト秒レーザによる高確度角度計測}

2 軸光ナノグリッドを利用して, 光周波数コムを角度スケ 一ルコムに変換する原理を図 2 に示す 1)2). 超短パルスレー ザであるモード同期フェムト秒レーザ (光周波数コム) は, 光周波数域において等周波数間隔で並んだ発振モードを有 しており, 現在は日本の長さ国家標準にも用いられている. 光周波数コムレーザを 2 軸光ナノグリッドに入射すると, その分光作用により 1 次回折光群が生成されるが, 各コム モードの光周波数はそれぞれの 1 次回折光の回折角と一対 一の関係にあることから，高安定な角度スケールコムとし て活用できる.また，レーザオートコリメーション法と融合 し, 光周波数域で角度スケールコムを捕捉することで, 分解 能 0.1 arc-second 超での高精度な「つながる」高確度角度計 測を実現できる ${ }^{3)}$.

\section{3. 大面積 2 軸回折スケール格子の一括露光}

国家標準にダイレクトにリンクした「つながる」超精密光 計測技術の開発に必須となる, 大面積 2 軸光ナノグリッド を生成する光学系を図 3 に示す ${ }^{4)}$. 露光基板と 2 枚の反射鏡 からなる非直交型ロイドミラー干涉光学系によるマルチビ 一ム干涉露光は, 各サブビーム間の非共通光路が短いこと もあり高安定な 2 軸干渉縞定在波を生成可能である.これ に独自の偏光制御を融合することで, 2 軸干涉縞定在波を高 精度化できる.これまでに $100 \mathrm{~mm}$ 四方サイズの大面積高精 度 2 軸光ナノグリッド（格子ピッチ: $1 \mu \mathrm{m}$ ）の一括転写に成 功している ${ }^{5)}$. なお, 回折格子をスケールとして用いるリニ アェンコーダ, サーフェスエンコーダにおいては, 格子ピッ チが変位計測の「目盛り」として用いられている ${ }^{6) か ゙ ， そ の ~}$ 校正評価を長さの国家標準に直結した形態で実現できれば,

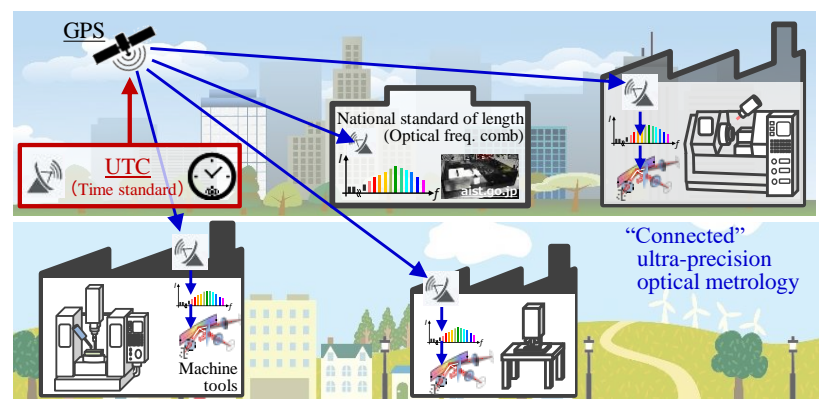

Fig.1 A schematic of the "connected" ultra-precision optical metrology

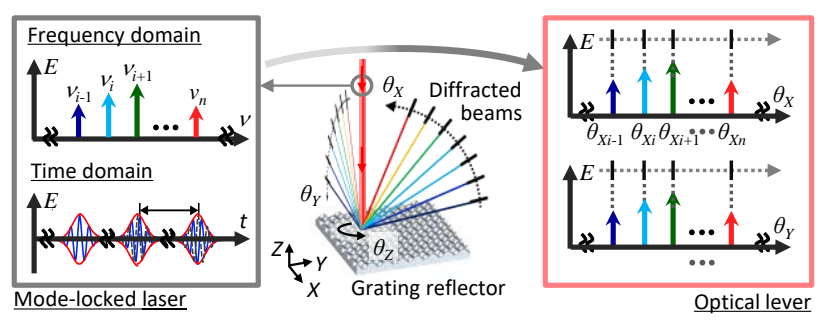

Fig.2 Angle scale comb generated from an optical frequency $\mathrm{comb}^{2)}$

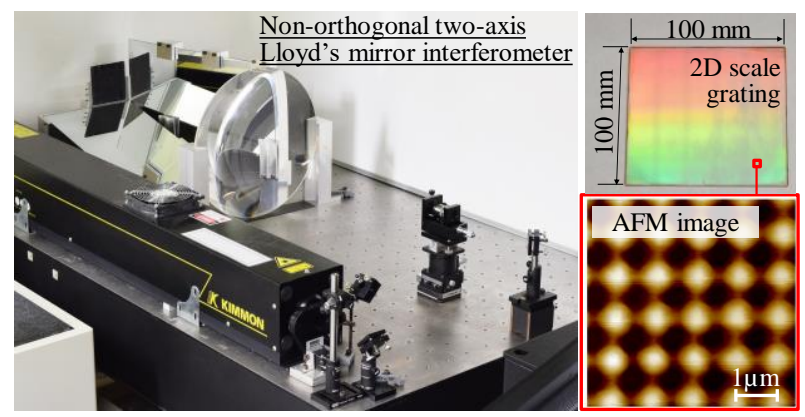

Fig.3 Fabrication of a large-area two-dimensional scale grating based on the interference lithography

様々な超精密加工機, 超精密計測機を, それら装置が置かれ た「その場」で超高精度に校正可能な，全く新たな信頼性保 証体系を確立できる. 現在, その実現に向け，長尺リニアス ケールおよび大面積 2 軸光ナノグリッドの格子ピッチを迅 速・高精度に評価する光学的手法の開発を鋭意進めている.

\section{文献}

(1) Y. Shimizu et al., Applied Sciences, 10-11, (2020) 3037 (22pp)

(2) Y. Shimizu et al., Prec. Eng., 47, (2017) 72-80

(3) Y.L. Chen, Yuki Shimizu et al., Prec. Eng., 54, (2018) 284-293

(4) Y. Shimizu et al., Prec. Eng., 52, (2018) 138-151

(5) Y. Shimizu et al., Prec. Eng., 60 (2019) 280-290

(6) Y. Shimizu et al., Sensors, 19-23 (2019) 5289 (33pp) 